\title{
The European Convention of Human Rights and Migration at Sea: Reading the "Jurisdictional Threshold" of the Convention Under the Law of the Sea Paradigm
}

\author{
Efthymios Papastavridis*
}

(Received 23 February 2020; accepted 03 March 2020)

\begin{abstract}
In all the applications before the ECtHR concerning migration at sea, a preliminary, yet seminal, question is whether the applicants were within the jurisdiction of the respondent State, in terms of Article 1 of the European Convention on Human Rights (ECHR). This question becomes even more apposite in contemporary situations of remote interception or search and rescue operations. In addressing the matter of jurisdiction in such cases, the law of the sea becomes of significant importance. This Article argues that as the International Tribunal of the Law of the Sea (ITLOS) has often taken into account human rights considerations, similarly, the European Court of Human Rights should read into the term "jurisdiction" under Article 1 of ECHR law of the sea considerations. Far from resurrecting Banković and the strict "general international law" notion of jurisdiction under ECHR, this Article only intends to shed some light on when a State would be considered as exercising such "authority and control over persons" in the maritime domain. In so doing, this Article will focus only on the potential application of the ECHR to the most common practices of States vis-à-vis migration on the high seas, namely interception and rescue operations.
\end{abstract}

Keywords: European Convention on Human Rights; extraterritorial application; law of the sea; jurisdiction; maritime migration

\section{A. Introduction}

In May 2018, an application was brought against Italy before the European Court of Human Rights (ECtHR) for violations of Article 2 (right to life), Article 3 (prohibition of torture and inhumane or degrading treatment), and Article 4 of Protocol 4 (prohibition of collective expulsions) of the European Convention on Human Rights (ECHR). ${ }^{1}$ The pending S.S. and Others v. Italy case was brought by the Global Legal Action Network (GLAN) and concerned an incident on November 6, 2017 in which the Libyan Coast Guard, with Italy's connivance, allegedly interfered

\footnotetext{
${ }^{*}$ Postdoctoral Researcher in International Law of the Sea at the Faculty of Law of Oxford University. This Article was first presented at a workshop on "Accountability for Human Rights Violations in Migration Control" held in Oxford on Nov. 10, 2018, that was funded by an ERC Starter Grant RefMig (Grant Agreement 716968), of which Cathryn Costello is the PI. The author would like to express his gratitude to Cathryn Costello, Itamar Mann, Nora Markard, Miles Jackson, Sotiris Lekkas, and Cal Musto for having read and offered valuable comments on previous drafts of this Article. The usual disclaimer applies. <papastavridis@academyofathens.gr>

${ }^{1}$ European Convention for the Protection of Human Rights and Fundamental Freedoms, Nov. 4, 1950, 213 U.N.T.S. 22 [hereinafter ECHR].
}

(C) The Author(s) 2020. Published by Cambridge University Press on behalf of the German Law Journal. This is an Open Access article, distributed under the terms of the Creative Commons Attribution licence (http://creativecommons.org/licenses/by/4.0/), which permits unrestricted re-use, distribution, and reproduction in any medium, provided the original work is properly cited. 
in attempts by an NGO vessel to rescue 130 migrants from a sinking dinghy. ${ }^{2}$ A few months later, in August 2018, another application was brought against Italy before the same Court for alleged violations of the ECHR arising from the Aquarius incident. On June 10, 2018, Italy refused Aquariusa rescue vessel operated by the German NGO SOS Méditerranée and flagged to Gibraltar-access to its ports and the disembarkation of more than 600 rescued migrants on Italian territory. Eventually, Aquarius arrived safely in Valencia a week later and disembarked the migrants. ${ }^{3}$ Two of the rescued persons that ended up in Libya, however, brought a case against Italy-the pending C.O. and A.J. v. Italy-relating to that incident. An earlier application against Greece concerning the deaths of eleven refugees in a rescue operation in the Aegean Sea is still pending. ${ }^{4}$

These recent cases illustrate that the ECHR is very often the legal instrument that the "boat refugees" or "boat migrants" and their respective lawyers would turn to in order to seek redress in cases of loss of life or refoulement practices arising from interception or rescue operations at sea. The ECHR is not the only one in the context of maritime migration. Suffice to mention that similar cases have been brought before the UN Committee Against Torture (CAT), ${ }^{5}$ namely complaints arising from incidents involving the loss of life at sea of a person attempting to enter the Autonomous City of Ceuta by swimming, Sonko v. Spain, ${ }^{6}$ or the refoulement to Mauritania of persons rescued at sea, Marine $I^{7}{ }^{7}$ It is almost certain that such recourse to human rights courts and monitoring bodies will not cease. People have been crossing and will continue to cross borders to find refuge or a better life, and very often this occurs by sea. ${ }^{8}$ This was evident amidst the peak of the refugee crisis in 2015 in Europe and still holds true five years later. ${ }^{9}$ The response of European states to this phenomenon has been tailored towards averting the threat posed by maritime migration and enhancing the powers of the European Border and Coast Guard Agency

\footnotetext{
${ }^{2}$ See Stephanie Kirchgaessner \& Lorenzo Tondo, Italy's Deal with Libya to 'Pull Back' Migrants Faces Legal Challenge, THE GUARDIAN (May 8, 2018), https:/www.theguardian.com/world/2018/may/08/italy-deal-with-libya-pull-back-migrants-faceslegal-challenge-human-rights-violations. See also Moritz Baumgärtel, High Risk, High Reward: Taking the Question of Italy's Involvement in Libyan 'Pullback' Policies to the European Court of Human Rights, EJIL: TALK! (May 14, 2018), https://www. ejiltalk.org/high-risk-high-reward-taking-the-question-of-italys-involvement-in-libyan-pullback-policies-to-the-europeancourt-of-human-rights. On November 11, 2019, written submissions on behalf of the AIRE Centre, the Dutch Refugee Council (DCR), the European Council on Refugees and Exiles (ECRE), and the International Commission of Jurists (ICJ) were submitted to the ECtHR in relation to this case. S.S. and Others v. Italy, App. No. 21660/18 (Nov. 11, 2019), https://www.icj.org/wp-content/uploads/2019/11/ECtHR-SS_v_Italy_final-JointTPI-ICJECREAIREDCR-English-2019.pdf.

${ }^{3}$ See Mark Stone, Migrants from Aquarius Rescue Convoy Arrive in Port of Valencia, SKY News (June 17, 2018), https://news. sky.com/story/hundreds-of-migrants-on-aquarius-rescue-ship-set-to-arrive-in-spain-11407196. For a law of the sea commentary, see Efthymios Papastavridis, The Aquarius Incident and the Law of the Sea: Is Italy in Violation of the Relevant Rules?, EJIL: TALK! (June 27, 2018), https://www.ejiltalk.org/the-aquarius-incident-and-the-law-of-the-sea-is-italy-in-violation-of-therelevant-rules.

${ }^{4}$ Safi and Others v. Greece, App. No. 5418/15 (Jan. 21, 2015), http://hudoc.echr.coe.int/eng?i=001-161575 (communicating case to the Government in February 2016) [hereinafter Safi Case]; for further information, see EUROPEAN COURT OF HuMAN Rights, Press Country Profile: Greece (Nov. 2019), https://www.echr.coe.int/Documents/CP_Greece_ENG.pdf.

${ }^{5}$ The Committee Against Torture (CAT) is the body of ten independent experts that monitors implementation of the Convention Against Torture and Other Cruel, Inhuman or Degrading Treatment or Punishment. Convention Against Torture and Other Cruel and Inhuman or Degrading Treatment or Punishment, Dec. 10, 1984, 1465 U.N.T.S. 85. The Committee may also, under certain circumstances, consider individual complaints or communications from individuals claiming that their rights under the Convention have been violated. For more information on the work of CAT, see Office of the High Comm'r for Human Rights, Monitoring the Prevention of Torture and Other Cruel, Inhuman or Degrading Treatment or Punishment, U.N. HumAn RigHTs, https://www.ohchr.org/EN/HRBodies/CAT/Pages/CATIntro.aspx.

${ }^{6}$ Sonko (On Behalf of Sonko) v. Spain, U.N. Doc. CAT/C/47/D/368/2008 (Nov. 25, 2011).

${ }^{7}$ J.H.A. v. Spain, U.N. Doc. CAT/C/41/D/323/2007 (Nov. 21, 2008). For a comment on the case, see Kees Wouters \& Maarten Den Heijer, The Marine I Case: A Comment, 21 InT'L J. RefugeE L. 31 (2009).

${ }^{8}$ On migration by sea and the phenomenon of "boat people," see, inter alia, ITAMAR MANn, Humanity AT SEA: MARITIME Migration and the Foundations of International Law (2018); 'Boat Refugees' and Migrants at Sea: A Comprehensive Approach (Violeta Moreno-Lax \& Efthymios Papastavridis eds., 2016).

${ }^{9}$ As of December 23, 2019, 100,151 people have arrived in Europe by sea in 2019. See Operational Portal: RefugeE SitUATIONS, https://data2.unhcr.org/en/situations/mediterranean.
} 
(EBCG, formerly and widely known as FRONTEX). ${ }^{10}$ Thus, it is very likely that similar applications to the ECtHR or complaints before CAT, let alone actions for damages before the Court of Justice of the European Union (CJEU) arising in the context of FRONTEX operations, ${ }^{11}$ will be filed again.

In litigating or adjudicating such cases, especially in the context of ECHR, a preliminary, yet fundamental, question would be whether the persons concerned were within the jurisdiction of the respondent State, ${ }^{12}$ because only then the latter State would have been under an obligation to secure their rights under the relevant instrument. In other words, the issue of jurisdiction is a threshold requirement in the ECHR; the question of state responsibility would arise only after the ECtHR is satisfied that the matters complained of are within the jurisdiction of the respondent State. ${ }^{13}$ Particularly, in the S.S. and others and in the C.O. and A.J. v. Italy cases, the question of jurisdiction may prove the Achilles heel. Had the above persons been at the time of their (non-) rescue or of the diversion of their boat respectively within the jurisdiction of Italy in terms of Article 1 of ECHR? More broadly, do refugees or migrants come within the jurisdiction of a State that is remotely involved with the rescue operation or with the navigation of a vessel on the high seas, and if so, at what point of the operation?

It is such questions concerning the jurisdictional reach of the ECHR in the maritime domain that this Article attempts to address. This issue is not new; the ECtHR and other human rights courts have often ruled on cases involving maritime operations. ${ }^{14}$ Yet, there is merit in revisiting this issue in the light of the aforementioned very recent applications or incidents and from a different angle-such as from the angle of how the law of the sea understands the concept of jurisdiction. It is submitted that as the International Tribunal of the Law of the Sea (ITLOS) has often taken into account human rights considerations, ${ }^{15}$ similarly the ECtHR should import into the reading of the term jurisdiction law of the sea considerations.

\footnotetext{
${ }^{10}$ For the new vision of the EU regarding the management of external borders and migration, see, inter alia, STATE OF THE Union 2018: The Hour of EUROPEAN SovereIGNTY, https://ec.europa.eu/commission/sites/beta-political/files/soteu2018speech_en_0.pdf. For more information on FRONTEX operations, see FrONTEX: EuropeAn BORDER AND COAST GUARD AGENCY, https://frontex.europa.eu/. For academic commentary on the potential responsibility of FRONTEX for refoulement practices, see Roberta Mungianu, Frontex and Non-Refoulement: The International Responsibility of the EU (2016).

${ }^{11}$ Article 268 of the Treaty on the Functioning of the European Union states that " $[\mathrm{t}]$ he Court of Justice of the European Union shall have jurisdiction in disputes relating to compensation for damage provided for in the second and third paragraphs of Article 340." Article 340(2) states that "[i]n the case of non-contractual liability, the Union shall, in accordance with the general principles common to the laws of the Member States, make good any damage caused by its institutions or by its servants in the performance of their duties." Consolidated Version of the Treaty on the Functioning of the European Union arts. 268, 340(2), Oct. 26, 2012, 2012 O.J. (C 326) 47-390 [hereinafter TFEU]. See also Efthymios Papastavridis, The EU and the Obligation of Non-Refoulement at Sea, in Migration in the Mediterranean: Mechanisms of International Cooperation 236, 258-60 (Seline Trevisanut \& Francesca Ippolito eds., 2016); Melanie Fink, FronteX and Human Rights: Responsibility in 'Multi-Actor Situations' Under the ECHR and the EU Public Liability LAW (2018).

${ }^{12}$ ECHR art. 1 ("The High Contracting Parties shall secure to everyone within their jurisdiction the rights and freedoms defined in Section I of this Convention.").

${ }^{13}$ Isil Karakaş \& H. Bakırc1, Extraterritorial Application of the European Convention on Human Rights, in THE EUROPEAN Convention on Human Rights and General International Law 112, 113 (Anne van Aaken \& Iulia Motoć eds., 2018).

${ }^{14}$ See Hirsi Jamaa and Others v. Italy, App. No. 27765/09 (Feb. 23, 2012), http://hudoc.echr.coe.int/eng?i=001-109231 [hereinafter the Hirsi Case]; Medvedyev and Others v. France, App. No. 3394/03 (Mar. 29, 2010), http://hudoc.echr.coe. int/eng? $\mathrm{i}=001-97979$ [hereinafter Medvedyev Case]; Haitian Center for Human Rights v. United States, Case 10.675, Inter-Am. Comm'n H.R., Report No. 51/96, OEA/Ser.L/V/II.95, doc. 7 rev. (1997).

${ }^{15}$ For example, in the Juno Trader case, the ITLOS stated, " $\left.\mathrm{t}\right]$ he obligation of prompt release of vessels and crews includes elementary considerations of humanity and due process of law. The requirement that the bond or other financial guarantee must be reasonable indicates that a concern for fairness is one of the purposes of this provision.” Juno Trader (St. Vincent v. Guinea Bissau), Case No. 13, 128 ITLOS Rep. 267, para. 77; see also The "Enrika Lexie" Incident, (It. v. India) Provisional Measures, Case No. 24, Order of Aug. 24, 2015, paras. 94, 99, 104, https://www.itlos.org/cases/list-of-cases/case-no-24/.
} 
This is also dictated by the ECtHR itself; suffice it to quote the Court's pronouncement in the Jaloud v. The Netherlands case: "For the purposes of establishing jurisdiction under the Convention, the Court takes account of the particular factual context and relevant rules of international law." ${ }^{\prime 6}$ In that case, which involved extraterritorial conduct of armed forces in an occupied territory, the relevant rules that were examined consisted of the law of occupation under the 1907 Hague Regulations and the Fourth Geneva Convention, ${ }^{17}$ the pertinent UN Security Council Resolutions, and a network of Memoranda of Understanding defining the interrelations between the various armed contingents present in Iraq. ${ }^{18}$ Respectively, in a case involving the extraterritorial conduct of a State in the maritime domain, the relevant rules of international law to be taken into account could not but include those of the law of the sea. This would also be consistent with Article 31(3)(c) of the Vienna Convention on the Law of Treaties, which sets forth that in interpreting a treaty, for example, here the term jurisdiction under Article 1 of ECHR, " $[t]$ here shall be taken into account ... (c) any relevant rules of international law applicable in the relations between the parties," ${ }^{\prime 9}$ which in the maritime context are inevitably the rules of the international law of the sea.

That said, the Article does not intend to question the prevailing view that jurisdiction in various human rights treaties, including the ECHR, "refers to a power that a state exercises over a territory, and ... also over individuals .... This power is a question of fact, of actual authority and control." ${ }^{20}$ Rather, it only intends to shed some light on when a State would be considered as exercising such authority and control over persons in the maritime domain sufficient to bring about the application of the ECHR. The Article thus seeks to contribute to the discourse concerning issues of accountability for human rights violations in migration control, to which this Special Issue is devoted, especially with respect to new forms of contactless control of migrants at sea. ${ }^{21}$

Within the inevitable constraints of a single article it would be impossible to discuss all the ramifications of the interface of human rights law and the law of the sea. ${ }^{22}$ Thus, this Article will focus only on the potential application of the ECHR to the most common practices of States

\footnotetext{
${ }^{16}$ Jaloud v. The Netherlands, App. No. 47708/08, para. 141 (Nov. 20, 2014), http://hudoc.echr.coe.int/eng?i=001-148367 (emphasis added) [hereinafter the Jaloud Case].

${ }^{17}$ See, e.g., Regulations Concerning the Laws and Customs of War on Land arts. 42-56, Oct. 18, 1907; Convention (IV) Relative to the Protection of Civilian Persons in Time of War arts. 27-34, 47-78, Aug. 12, 1949. The rules on belligerent occupation were also considered for the purpose of establishing "jurisdiction" in Al-Jedda v. the United Kingdom, App. No. 27021/08, para. 77 (July 7, 2011), http://hudoc.echr.coe.int/eng?i=001-105612 [hereinafter Al-Jedda Case], and in Al-Skeini and Others v. United Kingdom, App. No. 55721/07, para. 143 (Jul. 7, 2011), http://hudoc.echr.coe.int/eng? $\mathrm{i}=001-105606$ [hereinafter the Al-Skeini Case].

${ }^{18}$ Jaloud Case, App. No. $47708 / 08$ at paras. $142-51$.

${ }^{19}$ See Vienna Convention on the Law of Treaties art. 31(3)(c), May 23, 1969, 1155 U.N.T.S. 331 [hereinafter VCLT]. For academic commentary, see Panos Merkouris, Article 31(3)(c) VCLT and the Principle of Systemic Integration: Normative Shadows in Plato's Cave (2015).

${ }^{20}$ Marko Milanovic, Extraterritorial Application of Human Rights Treaties: Law, Principles, and Policy 53 (2011). See also Ralph Wilde, Triggering State Obligations Extraterritorially: The Spatial Test in Certain Human Rights Treaties, 40 IsR. L. REV. 503, 508, 513-14 (2007); Olivier De Schutter, Globalization and Jurisdiction: Lessons from the European Convention on Human Rights, 6 BALTIC Y.B. INT'L L. 183 (2006). For contrary view see Banković and Others v. Belgium and Others, App. No. 52207/99, para. 61 (Dec. 12, 2001) [hereinafter the Banković Case].

${ }^{21}$ This term is coined and further analyzed in Violeta Moreno-Lax \& Mariagiulia Giuffré, The Rise of Consensual Containment: From 'Contactless Control' to 'Contactless Responsibility' for Forced Migration Flows, in RESEARCH Handbook on International Refugee Law 82-108 (Satvinder Singh Juss ed., 2017). See also the very interesting analysis of jurisdiction in cases of complicity to torture in Miles Jackson, Freeing Soering: The ECHR, State Complicity in Torture and Jurisdiction, 27 EUR. J. INT'L L. 817 (2016).

${ }^{22}$ See, e.g., Irini Papanicolopulu, International Law and the Protection of People at Sea (2018); Bernard Oxman, Human Rights and the United Nations Convention on the Law of the Sea, 36 Colum. J. TransnaT'L L. 404 (1998); Tullio Treves, Human Rights and the Law of the Sea, 28 BERKELEY J. INT'L L. 1 (2010); Efthymios Papastavridis, European Convention of Human Rights and the Law of the Sea: The Strasbourg Court in Unchartered Waters?, in THE INTERPRETATION AND APPLICATION OF THE European Convention of Human Rights: Legal and Practical Implications 117-46 (Malgosia Fitzmaurice \& Panos Merkouris eds., 2013).
} 
vis-à-vis migration on the high seas, namely interception and rescue operations, ${ }^{23}$ and will not address other human rights instruments or other potential breaches of human rights law arising in the maritime context. Accordingly, this Article will, first, succinctly expound how the ECtHR has addressed the question of jurisdiction in general and in the cases involving maritime operations. Then, the focus will shift to what jurisdiction means under the law of the sea, particularly in the context of interception operations and rescue at sea. It will conclude how the reading of jurisdiction under the law of the sea paradigm ought properly to inform the jurisprudence of the ECHR in cases like S.S. and others and C.O. and A.J. v. Italy.

\section{B. The Application of ECHR at Sea}

This section addresses the question of whether the ECHR applies extraterritorially, and particularly on the high seas. Focusing on its jurisdictional clause, it looks mainly at the interpretation given by the ECtHR to this clause in an extraterritorial setting and then on how this clause has been applied in the maritime context.

\section{Extraterritorial Application of the ECHR}

Article 1 contains the jurisdictional clause of the ECHR, according to which: "The High Contracting Parties shall secure to everyone within their jurisdiction the rights and freedoms defined in Section I of this Convention." ${ }^{24}$ As recognized by the ECHR, "the exercise of jurisdiction is a necessary condition for a Contracting State to be able to be held responsible for acts or omissions imputable to it which give rise to an allegation of the infringement of rights and freedoms set forth in the Convention." 25 Thus, it is imperative to construe the term jurisdiction for the purposes of the application of the ECHR.

First, it is true that the travaux préparatoires do not shed light on the term jurisdiction, ${ }^{26}$ and due to this fact and because of their supplementary nature as means of interpretation, ${ }^{27}$ the Court scarcely has recourse to them. ${ }^{28}$ Yet, in the seminal Bankovic case, the ECtHR referred to the preparatory works as confirmatory evidence of its reading of jurisdiction. ${ }^{29}$

In interpreting jurisdiction in that case, the Court favored the ordinary meaning of the term according to public international law, underscoring that a State's jurisdiction within the meaning of Article 1 is primarily territorial. ${ }^{30}$ According to the Court, "Article 1 of the Convention must be considered to reflect this ordinary and essentially territorial notion of jurisdiction, other bases of jurisdiction being exceptional and requiring special justification in the particular circumstances of each case." 31 In fact, however, such cases have proved to be not so exceptional.

\footnotetext{
${ }^{23}$ See Efthymios Papastavridis, The Interception of Vessels on the High Seas: Contemporary Challenges to the Legal ORder of the OCEANS 259-308 (2013).

${ }^{24}$ ECHR art. 1 (emphasis added).

${ }^{25}$ Catan and Others v. Moldova and Russia, App. Nos. 43370/04, 8252/05, and 18454/06, para. 103 (Oct. 19, 2012), http:// hudoc.echr.coe.int/eng?i=001-114082 [hereinafter the Catan Case].

${ }^{26}$ For the preparatory work of the ECHR, see Council of Europe, Collected Edition of the "Travaux Préparatoires” of the European Convention on Human Rights (1977); Michal Gondek, The Reach of Human Rights in a Globalising World: Extraterritorial Application of Human Rights Treaties 91 (2009).

${ }^{27}$ VCLT art. 32.

${ }^{28}$ Karen da Costa, The Extraterritorial Application of Selected Human Rights Treaties $93-94$ (2012).

${ }^{29}$ Banković Case, App. No. 52207/99 at paras. 63, 65.

${ }^{30}$ Banković Case, App. No. 52207/99 at para. 59.

${ }^{31}$ Banković Case, App. No. 52207/99 at para. 61. Rarely has an admissibility decision elicited such controversy and criticism. See, e.g., Marko Milanovic \& Tatjana Papic, As Bad as It Gets: The European Court of Human Rights's Behrami and Saramati Decision and General International Law, 58 INT'L \& CoMP. L.Q. 267 (2009); Georg Ress, Problems of Extraterritorial Human Rights Violations - the Jurisdiction of the European Court of Human Rights: The Banković Case, 12 IT. Y.B. INT'L L. 51, 63 (2002); Ralph Wilde, The "Legal Space" or "espace juridique" of the European Convention on Human Rights: Is It Relevant to
} 
As the ECHR itself acknowledges:

[T] o date, the Court has recognised a number of exceptional circumstances capable of giving rise to the exercise of jurisdiction by a Contracting State outside its own territorial boundaries. In each case, the question whether exceptional circumstances exist which require and justify a finding by the Court that the State was exercising jurisdiction extraterritorially must be determined with reference to the particular facts. ${ }^{32}$

For example, as an exception to the principle of territoriality, the Court has recognized that a Contracting State's jurisdiction under Article 1 may extend to acts of its authorities that produce effects outside its own territory. ${ }^{33}$

In addition, there is another strand of legal doctrine, significantly departing from the reading of jurisdiction under the Bankovic case, according to which jurisdiction denotes a certain kind of power, actual authority and control that a State exercises over territory or persons. ${ }^{34}$ "Jurisdiction, in this context, simply means actual power, whether exercised lawfully or not, nothing more, and nothing less." 35 "Facticity" in this regard "creates normativity" ${ }^{36}$ or, in the words of the ECtHR, "de facto control gives rise to de jure responsibilities."

Accordingly, the term jurisdiction:

has been understood in the extraterritorial context as a connection between the State, on the one hand, and either the territory in which the relevant acts took place-referred to as a spatial or territorial connection-or the individual affected by them-referred to as a personal or individual, or because of the type of State action involved, State-agent-authority connection. ${ }^{38}$

In the same vein, the ECHR Guide to Article 1 acknowledges that a State's jurisdiction outside its own border can primarily be established on the basis of the power or control actually exercised over the person of the applicant-ratione personae control-or on the basis of control actually exercised over the foreign territory in question-ratione loci control. ${ }^{39}$

The spatial model of jurisdiction was famously articulated in the Loizidou case dealing with Northern Cyprus, ${ }^{40}$ and applies to situations in which, as a consequence of lawful or unlawful

Extraterritorial State Action?, 2 Eur. Hum. RTs. L. REV. 115, 119 (2005); R.A. Lawson, Life after Banković: On the Extraterritorial Application of the European Convention on Human Rights, in ExTRATERrITORIAL APPLICATION OF Human Rights Treaties 83 (Fons Coomans \& Menno Kamminga eds., 2004).

${ }^{32}$ European Court of Human Rights, Guide on Article 1 of the European Convention on Human Rights 12 (2019), https://www.echr.coe.int/Documents/Guide_Art_1_ENG.pdf (emphasis added).

${ }^{33}$ Al-Skeini Case, App. No. 55721/07 at para. 133.

${ }^{34}$ See Milanovic, supra note 20, at 53. See also Ralph Wilde, The Extraterritorial Application of International Human Rights Law on Civil and Political Rights, in Routledge Handbook OF InTERnational Human Rights Law 635, 640 (Scott Sheeran \& Nigel Rodley eds., 2013).

${ }^{35}$ Marko Milanovic, From Compromise to Principle: Clarifying the Concept of State Jurisdiction in Human Rights Treaties, 8 Hum. RTs. L. REv. 411, 429 (2008).

${ }^{36}$ Martin Scheinin, Extraterritorial Effect of the International Covenant on Civil and Political Rights, in EXTRATERRITORIAL Application of Human Rights Treaties, supra note 31, at 73, 81.

${ }^{37} \mathrm{Al}-$ Saadoon and Mufdhi v. United Kingdom, App. No. 61498/08, para. 88 (June 30, 2009), http://hudoc.echr.coe.int/eng? $\mathrm{i}=001-97575$ [hereinafter the Al-Saadoon and Mufdhi Case].

${ }^{38}$ Ralph Wilde, Compliance with Human Rights Norms Extraterritorially: Human Rights Imperialism?, in INTERNATIONAL LAW AND THE Quest FOR ITS IMPlementation 319, 324 (Laurence Boisson de Chazournes \& Marcelo Kohen eds., 2010).

${ }^{39}$ European Court of Human Rights, supra note 32, at 13.

${ }^{40}$ Loizidou v. Turkey, App. No. 15318/89, para. 62 (Feb. 23, 1995), http://hudoc.echr.coe.int/eng?i=001-58007 ("Bearing in mind the object and purpose of the Convention, the responsibility of a Contracting Party may also arise when as a consequence of military action - whether lawful or unlawful-it exercises effective control of an area outside its national territory. The obligation to secure, in such an area, the rights and freedoms set out in the Convention, derives from the fact of such 
military action, a State exercises effective control of an area outside that national territory. "The obligation to secure, in such an area, the rights and freedoms set out in the Convention, derives from the fact of such control, whether it be exercised directly, through the Contracting State's own armed forces, or through a subordinate local administration." ${ }^{41}$ This notion of jurisdiction has similarly been applied in the contexts of Transnistria in Moldova, ${ }^{42}$ and Nagorno-Karabakh in Azerbaijan. ${ }^{43}$

With respect to the personal model, it is widely acknowledged that the exercise of control of a State official over a person abroad-usually in the form of abduction or detention-brings the person concerned under the jurisdiction of the State of nationality of the official. In an early and still frequently quoted case, Lopez Burgos v. Uruguay, the Human Rights Committee considered the applicability of the International Covenant on Civil and Political Rights (ICCPR) to the abduction, arrest, secret detention and torture of a Uruguayan citizen by Uruguay agents outside State territory. Interpreting Article 2(1) of the ICCPR, the Committee said that, "the reference to 'individuals subject to its jurisdiction' is not to the place where the violation occurred, but rather to the relationship between the individual and the State in relation to a violation of any of the rights set forth in the Covenant, wherever they occurred ...." ${ }^{44}$ This interpretation has been confirmed in its General Comment No. $31 .^{45}$

Noteworthy is that recently, in its 2018 General Comment No. 36 on the right of life, the Human Rights Committee seems to go a step further and espouse an impact approach as a complement to the personal model. In interpreting the term jurisdiction under Article 2 in connection with the right of life under Article 6 of the ICCPR, the Committee opined that "this includes persons located outside any territory effectively controlled by the State, whose right to life is nonetheless impacted by its military or other activities in a direct and reasonably foreseeable manner." 46 The Committee against Torture has also adopted the personal model. ${ }^{47}$

In the ECHR context, the personal model has been very often upheld, even pre-Bankovic, ${ }^{48}$ but mainly post-Banković-for example, in Öcalan v. Turkey, where the Grand Chamber found that

control whether it be exercised directly, through its armed forces, or through a subordinate local administration."). See also Cyprus v. Turkey, App. No. 25781/94, para. 77 (May 10, 2001), http://hudoc.echr.coe.int/eng?i=001-59454.

${ }^{41}$ Catan Case, App. Nos. 43370/04, 8252/05, and 18454/06 at para. 106.

${ }^{42}$ See Ilaşcu and Others v. the Republic of Moldova and Russia, App. No. 48787/99, paras. 310-19 (Jul. 8, 2004), http:// hudoc.echr.coe.int/eng?i=001-61886; Catan Case, App. Nos. 43370/04, 8252/05, and 18454/06 at paras. 116-23; Mozer v. the Republic of Moldova and Russia, App. No. 11138/10, paras. 109-11 (Sept. 23, 2016), http://hudoc.echr.coe.int/eng?i=001161055 .

${ }^{43}$ Chiragov and Others v. Armenia, App. No. 13216/05, paras. 169-86 (June 16, 2015), http://hudoc.echr.coe.int/eng? i=001-155353; Sargsyan v. Azerbaijan, App. No. 40167/06, paras. 14-28 (June 16, 2015), http://hudoc.echr.coe.int/eng? $\mathrm{i}=001-155662$.

${ }^{44}$ Hum. Rts. Committee, Lopez Burgos v. Uruguay, para. 12.1, U.N. Doc. A/36/40 (July 29, 1981). See also Celiberti de Casariego v. Uruguay, para. 10.3., U.N. Doc. CCPR/C/13/D/56/1979 (July 29, 1981).

${ }^{45}$ Hum. Rts. Committee, General Cmt. No. 31:The Nature of the General Legal Obligation Imposed on States Parties to the Covenant, U.N. Doc. CCPR/C/21/Rev.1/Add.13, at 10, 11 (2004).

${ }^{46} \mathrm{Hum}$. Rts. Committee, General Cmt. No. 36, on Article 6 of the International Covenant on Civil and Political Rights, on the right to life, CCPR/C/GC/36 (30 October 2018), para. 63, https://tbinternet.ohchr.org/Treaties/CCPR/Shared\%20Documents/ 1_Global/CCPR_C_GC_36_8785_E.pdf (emphasis added). For further commentary, see Daniel Møgster, Towards Universality: Impacting the Enjoyment of the Right to Life and the Extraterritorial Application of the ICCPR, EJIL: TALK! (Nov. 27, 2018), http://www.ejiltalk.org/towards-universality-activities-impacting-the-enjoyment-of-the-right-to-life-andthe-extraterritorial-application-of-the-iccpr.

${ }^{47}$ Committee Against Torture, General Cmt. No. 2, Implementation of Article 2 by States Parties, U.N. Doc. CAT/C/GC/2 (2008). See also Committee Against Torture, Conclusions and Recommendations: United Kingdom of Great Britain and Northern Ireland, U.N. Doc. CAT/C/CR/33/3, at 4(b) (2004). For the extraterritorial application of the EU Charter on Fundamental Human Rights, see Violeta Moreno-Lax \& Cathryn Costello, The Extraterritorial Application of the EU Charter of Fundamental Rights: From Territoriality to Facticity-the Effectiveness Model, in THE EU CHARTER OF Fundamental Rights: A Commentary 1657 (Steve Peers et al. eds., 2014).

${ }^{48}$ See, e.g., Drozd and Janusek v. France and Spain, App. No. 12747/87, para. 91 (June 26, 1992), http://hudoc.echr.coe.int/ eng?i=001-57774 (describing the secondment of French and Spanish judges to Andorra); X v. The United Kingdom, 
Turkey had exercised extraterritorial jurisdiction when detaining and abducting the applicant from Kenya, ${ }^{49}$ in Pad and others $v$. Turkey concerning the killing of the applicant's relatives by firing from a helicopter, ${ }^{50}$ and in Al-Saadoon and Mufdhi $v$. UK in relation to the imprisonment of the applicants in a British-run military prison in Iraq. ${ }^{51}$ In the famous Al-Skeini $v$. UK case, the Court reaffirmed the validity both of the spatial model and the personal model, concluding with regard to the latter that, "it is clear that, whenever the State through its agents exercises control and authority over an individual, and thus jurisdiction, the State is under an obligation under Article 1 to secure to that individual the rights and freedoms under Section 1 of the Convention that are relevant to the situation of that individual." 52

As an alternative to the above two models, it has been proposed that a distinction should be drawn between the positive obligation of States to secure or ensure human rights, which extends even to preventing human rights violations by third parties, and the negative obligation of States to respect human rights, which only requires states to refrain from interfering with the rights of individuals without sufficient justification. Under this model, on the one hand, the positive obligation would be predicated on a state having effective overall control over an area, while on the other hand, the negative obligation to respect human rights would be territorially unlimited ${ }^{53}$ Without dwelling upon its merits, it readily appears that, even under this position, a certain level of control and authority over territory or persons is still needed for the ECHR to come into play.

In conclusion, the ECtHR has consistently broadened the ratione loci scope of the ECHR by accepting that the contracting States will be bound by the Convention, even extraterritorially, when they exert either effective control over territory or authority and control over persons. Admittedly, because human rights can be "divided and tailored," 54 there is a difference on which rights a State is called to secure when acting under the personal model or the spatial one, which depends on the circumstances of each case. ${ }^{55}$ At any rate, there is room for the assertion that control entails responsibility. For example, the extent to which contracting parties must secure the rights and freedoms of individuals outside their borders is commensurate with the extent of their control over these individuals. ${ }^{56}$

\section{Application of the ECHR on the High Seas}

In the maritime context and in particular, on the high seas, the situation is rather unambiguous in light of the jurisprudence of the ECtHR: The ECHR applies on the high seas, insofar as control, and therefore, jurisdiction, is exerted by organs of the State parties, usually warships or other duly authorized state vessels. This assertion is supported by the Xhavara v. Albania and Italy case, ${ }^{57}$ involving the sinking of an Albanian vessel by an Italian warship on the high seas,

App. No. 7547/76 (Dec. 15, 1977), http://hudoc.echr.coe.int/eng?i=001-74380 (stating the decision of the now defunct European Commission of Human Rights); M. v. Denmark, App. No. 17392/90 (Oct. 14, 1992), http://hudoc.echr.coe.int/ eng?i=001-1390. Both $X v$. The United Kingdom and M. v. Denmark concerned the exercise of jurisdiction on foreign soil through consulates and embassies.

${ }^{49}$ See Öcalan v. Turkey, App. No. 46221/99, para. 91 (Mar. 12, 2003), http://hudoc.echr.coe.int/eng?i=001-69022.

${ }^{50}$ See Pad and Others v. Turkey, App. No. 60167/00, para. 53 (June 28, 2007), http://hudoc.echr.coe.int/eng?i=001-81672.

${ }^{51}$ See Al-Saadoon and Mufdhi Case, App. No. 61498/08 at paras. 88-89. See also Hassan v. The United Kingdom, App. No. 29750/09, paras. 75-80 (Sept. 16, 2014), http://hudoc.echr.coe.int/eng?i=001-146501.

${ }^{52}$ Al-Skeini Case, App. No. 55721/07 at para. 137.

${ }^{53}$ See Milanovic, supra note 20, at 209-22.

${ }^{54}$ As the Court in the Al-Skeini case famously noted, "whenever the State, through its agents, exercises control and authority over an individual, and thus jurisdiction, the State is under an obligation under Article 1 to secure to that individual the rights and freedoms under Section I of the Convention that are relevant to the situation of that individual." In this sense, therefore, the Convention rights can be "divided and tailored." Al-Skeini Case, App. No. 55721/07 at para. 137.

${ }^{55}$ See also Milanovic, supra note 20 , and accompanying text.

${ }^{56}$ See Lawson, supra note 31 , at 120.

${ }^{57}$ See Xhavara and Others v. Italy and Albania, App. No. 39473/98 (Jan. 11, 2001), http://hudoc.echr.coe.int/eng?i=001-31884. 
and by the Rigopoulos $v$. Spain case ${ }^{58}$ involving the arrest of a drug trafficking vessel on the high seas, in which cases the jurisdiction ratione loci of the Court was never contested. In the 2010 Medvedyev v. France case, the Grand Chamber addressed this issue succinctly and held that:

[A]s this was a case of France having exercised full and exclusive control over the Winner and its crew, at least de facto, from the time of its interception, in a continuous and uninterrupted manner until they were tried in France, the applicants were effectively within France's jurisdiction for the purposes of article 1 of the Convention. ${ }^{59}$

Also, in the 2012 Hirsi case, which concerned Somalian and Eritrean migrants who had been intercepted on the high seas by the Italian authorities and sent back to Libya, the Grand Chamber held that:

[T] he events took place entirely on board ships of the Italian armed forces, the crews of which were composed exclusively of Italian military personnel. In the Court's opinion, in the period between boarding the ships of the Italian armed forces and being handed over to the Libyan authorities, the applicants were under the continuous and exclusive de jure and de facto control of the Italian authorities . . . Accordingly, the events giving rise to the alleged violations had fallen within Italy's jurisdiction within the meaning of Article $1 .{ }^{60}$

Hence, the Hirsi case comes to complement the above decisions and fully substantiate the argument that the ECHR applies on the high seas. This has also been affirmed in more recent cases involving drug trafficking at sea ${ }^{61}$ and piracy off the coast of Somalia. ${ }^{62}$

As expounded above, the application of the ECHR on the high seas presupposes a certain degree of factual control over the vessel or over the persons that are to come under the jurisdiction of the boarding State. Such degree of control would clearly be satisfied in cases of boarding and search of the vessel and when suspects are detained and transferred to the judicial authorities of the State party to the Convention-such as in the Medvedyev case-or when they are transferred to a third State- such as in the Hirsi case. It may also be satisfied in cases when there is a ship-toship operation prior to boarding, which involves limited use of force to bring the delinquent vessel to a halt. For example, by way of analogy, in the Andreou v. Turkey case, the ECtHR stated that "the opening of fire on the crowd from close range ... was such that the applicant must be regarded as within the jurisdiction of Turkey." ${ }^{63}$ In a similar vein, in the Women on Waves $v$. Portugal case, the Court regarded that mere interception, without boarding, by a Portuguese warship was sufficient to bring the Convention into application. ${ }^{64}$ In order to enforce the then national legislation prohibiting abortion, the Portuguese authorities sent a warship to intercept a Dutch-flagged vessel, the Borndiep, outside the territorial waters of Portugal. The warship

\footnotetext{
${ }^{58}$ See Rigopoulos v. Spain, App. No. 37388/97 (Jan. 12, 1999), http://hudoc.echr.coe.int/eng?i=001-5625.

${ }^{59}$ See Medvedyev Case, App. No. 3394/03 at para. 67. For commentary on the case, see Douglas Guilfoyle, Medvedyev and Others v. France, European Court of Human Rights, 25 INT'L J. MARINE \& COASTAL L. 437 (2010); Efthymios Papastavridis, European Court of Human Rights Medvedyev et al. v. France (Grand Chamber, Application No. 3394/03) Judgment of 29 March 2010, 59 INT'L \& COMP. L.Q. 867 (2010).

${ }^{60}$ Hirsi Case, App. No. 27765/09 at paras. 81, 82. For commentary, see Mariagiulia Giuffré, Waterdowned? Rights on the High Seas: Hirsi Jamaa and Others v Italy (2012), 61 INT'L \& COMP. L Q. 728 (2012).

${ }^{61}$ See Vassis and Others v. France, App. No. 62736/09 (June 27, 2013), http://hudoc.echr.coe.int/eng?i=001-122306.

${ }^{62}$ Ali Samatar and Others v. France, App. Nos. 17110/10 and 17301/10 (Dec. 4, 2014), http://hudoc.echr.coe.int/eng?i=001148290; Hassan and Others v. France, App. Nos. 46695/10 and 54588/10 (Dec. 4, 2014), http://hudoc.echr.coe.int/eng?i=001148289.

${ }^{63}$ Andreou v. Turkey, App. No. 45653/99, para. A.3.c. (June 3, 2008), http://hudoc.echr.coe.int/eng?i=001-95295.

${ }^{64}$ See Women on Waves and Others v. Portugal, App. No. 31276/05, para. 23 (Jan. 13, 2009), http://hudoc.echr.coe.int/eng? $\mathrm{i}=$ 001-91046 [hereinafter the Women on Waves Case].
} 
notified the captain of the Borndiep of the decision not to grant entry within its territorial waters and positioned itself next to the Borndiep to effectively prevent entry. ${ }^{65}$

Arguably, however, the law of the sea can afford a different or broader reading of the jurisdictional threshold of the Convention when its application at sea is at issue. Because the law of the sea includes the "relevant rules of international law" and the international law background against which the "jurisdiction" under Article 1 ECHR in such cases will be assessed ${ }^{66}$ or interpreted, ${ }^{67}$ it may provide significant insights on how the latter term shall be construed. Thus, the next section will discuss how jurisdiction is understood under the law of the sea paradigm and how this understanding may influence the interpretation of the term jurisdiction under ECHR, as applicable at sea.

\section{Jurisdiction on the High Seas Under the Law of the Sea Paradigm and the ECHR}

It is trite to remark that in the law of the sea context, jurisdiction is everything. A-if not the-central function of the UN Convention on the Law of the Sea (LOSC), ${ }^{68}$ often dubbed the "constitution of oceans," 69 is to allocate jurisdiction amongst port, coastal, and flag States. Thus, in relation to various activities, the LOSC ascribes to States both prescriptive jurisdiction-for example, the power to make laws, decisions, or rules-and enforcement jurisdiction - the power to take executive or judicial action in pursuance of or consequent to the making of decisions or rules. ${ }^{70}$ As Gavouneli asserts, "[i]t is quite clear, however, that ultimately the legal basis of all aspects of jurisdiction remains the same, namely State sovereignty - and whatever the label attached, jurisdiction remains the external manifestation of the power of the State."71

The way that the law of the sea approaches when and how a State may interfere with the navigation of a vessel on the high seas and States' rights and obligations in respect of search and rescue operations, arguably has significant consequences for the circumstances in which the ECHR will apply, especially in the context of "contactless control" operations.

\section{Interference with Navigation on the High Seas and the ECHR}

Article 86 LOSC negatively defines the fundamental principle of the freedom of the high seas to begin at all parts of the sea that are not included in the Exclusive Economic Zone (EEZ) - up to 200 nautical miles from coastal baselines - or in the territorial sea-up to 12 nautical miles from the baselines. ${ }^{72}$ This principle is predominantly of a negative nature. According to the $1950 \mathrm{UN}$ Memorandum on the Regime of the High Seas, " $[t]$ he essential idea underlying the principle of

\footnotetext{
${ }^{65}$ See Kristof Gombeer \& Melanie Fink, Non-Governmental Organizations and Search and Rescue at Sea, 4 MAR. SAFETY \& MAR. SECURITY L.J. 1, 12-13 (2018).

${ }^{66}$ Jaloud Case, App. No. 47708/08 at paras. 141-51; Al-Jedda Case, App. No. 27021/08 at para. 77; Al-Skeini Case, App. No. 55721/07 at para. 143; Regulations Concerning the Laws and Customs of War on Land arts. 42-56, Oct. 18, 1907; Convention (IV) Relative to the Protection of Civilian Persons in Time of War arts. 27-34, 47-78, Aug. 12, 1949.

${ }^{67}$ See VLCT art. 31(3)(c).

${ }^{68}$ United Nations Convention on the Law of the Sea, Nov. 16, 1994, 1833 U.N.T.S. 3 [hereinafter LOSC].

${ }^{69}$ See Tommy T. B. KoH, A CONSTITUTION FOR THE OCEANS www.un.org/Depts/los/convention_agreements/texts/ koh_english.pdf. See also R. R. Churchill, 10 Years of the UN Convention on the Law of the Sea - Towards a Global Ocean Regime? A General Appraisal, 48 German Y.B. InT'L L. 81, 84-88 (2005).

${ }^{70}$ James Crawford, Brownlie's Principles of Public InTERnational LaW 440 (9th ed. 2015). On jurisdiction under general international law, see, inter alia, F.A. Mann, The Doctrine of Jurisdiction in International Law, 111 RECUEIL DES COURS 1, 1-112 (1964); CEDRIC RYNGAerT, Jurisdiction IN InTERNATIONAL LAW (2008); Michael Akehurst, Jurisdiction in International Law, 46 BRIT. Y.B. INT'L L. 145 (1972-1973).

${ }^{71}$ Maria Gavouneli, Functional Jurisdiction in the Law of the Sea 6 (2007).

${ }^{72}$ See LOSC art. 86.
} 
freedom of the high seas is the concept of the prohibition of interference in peacetime by ships flying one national flag with ships flying the flag of other nationalities."

Inexorably linked with this prohibition of interference with non-national vessels is the principle of exclusivity of flag State jurisdiction, namely that ships on the high seas are, as a general rule, subject to the exclusive jurisdiction and authority of the state whose flag they lawfully fly. ${ }^{74}$ As Article 92 sets out, "[s]hips shall sail under the flag of one State only and, save in exceptional cases expressly provided for in international treaties or in this Convention, shall be subject to its exclusive jurisdiction on the high seas." As to the kind of jurisdiction that flag States enjoy over their vessels on the high seas, Guilfoyle rightly contends that:

[D]espite its wording, Art. 92 creates no absolute prohibition on States extending their prescriptive or regulatory jurisdiction to events occurring aboard a foreign vessel ... The prohibition is upon States exercising enforcement jurisdiction over foreign vessels on the high seas. The interest thus preserved is each State's interest in freedom of navigation. ${ }^{75}$

Thus, the principle of exclusive flag State jurisdiction goes hand in hand with the freedom of navigation, one of the main freedoms of the high seas, included in Article 87 of LOSC, which States also enjoy in other States' EEZs pursuant to Article 58(1) of LOSC.

On the face of Article 92 LOSC and in accordance with general international law, exceptions of the exclusive enforcement jurisdiction of the flag State are the exercise of the right of visit per Article 110 LOSC, $^{76}$ the right of hot pursuit per Article 111 LOSC, ${ }^{77}$ and any enforcement power-including the boarding, search, seizure, or diversion of the vessel concerned-exercised with the consent of the flag State, either treaty-based ${ }^{78}$ or ad hoc. ${ }^{79}$ Only under these circumstances may third States lawfully interfere with the navigation of vessels on the high seas, provided also that this interference is in accordance with the relevant provisions of LOSC or other applicable treaties and with the principles of reasonableness, necessity, and proportionality under international law. ${ }^{80}$ Such interference constitutes an exercise of enforcement jurisdiction, because

\footnotetext{
${ }^{73}$ Memorandum on the Regime of the High Seas by the Secretariat, U.N. Doc. A/CN 4/32 (1950), reprinted in [1950] 2 Y.B. Int'l L. Comm'n 67, 69, U.N. Doc. (translation). See also S.S. Lotus Case (Fr. v. Turk.), Judgment No. 9, 1927 P.C.I.J. (ser. A) No. 10, at 25. On the S.S. Lotus case, see Photini Pazartzis, Judicial Activism and Judicial Self-Restraint: The PCIJ's Lotus Case, in Legacies of the Permanent Court of International Justice 319 (2013).

${ }^{74}$ See generally D.P. O'CONnell, The International LAW of the SEA: Volume II 796 (I.A. Shearer ed., 1984); Robert JenNings \& Arthur WatTs, Oppenheim's InTERnATIONAL LAW 737 (9th ed. 1992).

${ }^{75}$ Douglas Guilfoyle, Article 92, in UN Convention on the Law of the Sea: A Commentary 702-03 (Alexander Proelß ed., 2017).

${ }^{76}$ Under Article 110 LOSC:
}

[E]xcept where acts of interference derive from powers conferred by treaty, a warship which encounters on the high seas a foreign ship ... is not justified in boarding it unless there is reasonable ground for suspecting that: (a) the ship is engaged in piracy; (b) the ship is engaged in the slave trade; (c) the ship is engaged in unauthorized broadcasting and the flag State of the warship has jurisdiction under article 109; (d) the ship is without nationality; or (e) though flying a foreign flag or refusing to show its flag, the ship is, in reality, of the same nationality as the warship.

${ }^{77}$ See, for example, Nicholas Poulantzas, The Right of Hot Pursuit in International Law (2002), for more information on hot pursuit. See also Arctic Sunrise Arbitration (Netherlands v. Russia), Case No. 2014-02, Merits, Award of 14 August 2015, paras. 245-75 (Perm. Ct. Arb. 2015) [hereinafter the Arctic Sunrise Case].

${ }^{78}$ See, for example, Protocol Against the Smuggling of Migrants by Land, Sea and Air Supplementing the United Nations Convention Against Transnational Organized Crime art. 8(2), Jan. 28, 2004, 2241 U.N.T.S. 507 [hereinafter the Smuggling of Migrants Protocol], for maritime migration purposes.

${ }^{79}$ See PAPASTAVRIDIS, supra note 23, at 63-66 on ad hoc consent. See also Robert Reuland, Interference with Non-National Ships on the High Seas: Peacetime Exceptions to the Exclusivity Rule of the Flag State Jurisdiction, 22 VAND. J. TRANSNAT'L L. 1161-229 (1989); I.A. Shearer, Problems of Jurisdiction and Law Enforcement Against Delinquent Vessels, 35 INT'L \& ComP. L.Q. 320, 336-39 (1986).

${ }^{80}$ Arctic Sunrise Case, Case No. 2014-02 at para. 197; Duzgit Integrity Arbitration (Malta v. São Tomé and Príncipe), Case No. 2014-17, Award of 5 September 2016, para. 209 (Perm. Ct. Arb. 2016). 
it constitutes "power to take executive ... action in pursuance of or consequent on the making of decisions or rules," ${ }^{81}$ here, the relevant treaties and the national legislation on law enforcement at sea. ${ }^{82}$

The next question is: What would amount to such assertion of enforcement jurisdiction vis-àvis a foreign flag on the high seas? Needless to say, actions such as the boarding and search of the vessel concerned as well as its seizure ${ }^{83}$ and diversion to ports, fall under the scope of the abovementioned treaty provisions and hence within the remit of enforcement jurisdiction. But what about other actions not necessarily involving the physical interference with the vessel? In the light of a very recent pronouncement of ITLOS in the $2019 \mathrm{M} / \mathrm{V}$ Norstar case, there is room for the argument that any action that would have as a consequence the interference with the freedom of navigation would constitute a-lawful or unlawful, depending on whether it is justified under international law-exercise of jurisdiction at sea ${ }^{84}$ In the view of the Tribunal:

It goes without saying that physical or material interference with navigation of foreign ships on the high seas violates the freedom of navigation ... However, even acts which do not involve physical interference or enforcement on the high seas may constitute a breach of the freedom of navigation. In this regard, the Tribunal notes that Italy recognizes the possibility that acts falling short of enforcement action on the high seas could be relevant in terms of a breach of article 87 of the Convention, if such acts produce some "chilling effect."

One may argue, for example, that whenever a State issues a decree of seizure of a foreign-flagged vessel that has rescued migrants on the high seas, this may amount to a breach of the freedom of navigation under the LOSC. As the Tribunal ruled:

Regardless of such [chilling] effect, any act which subjects activities of a foreign ship on the high seas to the jurisdiction of States other than the flag State constitutes a breach of the freedom of navigation, save in exceptional cases expressly provided for in the Convention or in other international treaties. ${ }^{86}$

It should, however, be noted that this pronouncement was heavily criticized by a joint dissenting opinion of seven judges of the ITLOS. ${ }^{87}$ Indeed, it seems as an overly expansive interpretation of the freedom of navigation and of the principle of exclusive jurisdiction of the flag State because it proscribes not only the assertion of enforcement, but also of prescriptive jurisdiction by third States over activities on the high seas, regardless of whether those States may have a jurisdictional nexus with those activities. ${ }^{88}$ It remains to be seen whether this finding of the ITLOS will be upheld by other international courts and tribunals in future cases and to what extent it will influence the

\footnotetext{
${ }^{81}$ CRAWFORD, supra note 70, at 440. On jurisdiction under general international law, see, for example, Mann, supra note 70 ; RYNGAERT, supra note 70; Akehurst, supra note 70.

${ }^{82}$ See, e.g., The Commander's Handbook on the Law of Naval Operations, NPW 1-14M (Aug. 2017), https://www. jag.navy.mil/distrib/instructions/CDRs_HB_on_Law_of_Naval_Operations_AUG17.pdf.

${ }^{83} \mathrm{Cf}$. LOSC art. 105 (comparing in relation to seizure of pirate vessels).

${ }^{84}$ This resembles the "effect-approach" adopted by the Human Rights Committee; see Hum. Rts. Committee, supra note 46, at para. 63.

${ }^{85} \mathrm{M} / \mathrm{V}$ Norstar (Pan. v. It.), Case No. 25, Judgment of Apr. 10, 2019, paras. 222-23, https://www.itlos.org/fileadmin/itlos/ documents/cases/case_no.25/Judgment/C25_Judgment_10.04.pdf [hereinafter the M/V Norstar Case].

${ }^{86} I d$. at para. 224.

${ }^{87}$ See the very thoughtful Joint Dissenting Opinion of Judges Cot, Pawlak, Yanai, Hoffmann, Kolodkin, Lijnzaad, and Treves, in particular para. 36. M/V Norstar (Pan. v. It.), Case No. 25, Joint Dissenting Opinion, para. 36, https://www. itlos.org/fileadmin/itlos/documents/cases/case_no.25/Judgment/C25_DO_joint.pdf.

${ }^{88}$ See Guilfoyle, supra note 75.
} 
prescriptive practice of States in relation to high seas activities. That said, in the particular context of migration at sea, the prescription of offenses related to smuggling of migrants by foreignflagged vessels could find its legal basis for the respective contracting parties on the $2000 \mathrm{UN}$ Convention against Transnational Organized Crime and its Protocol against the Smuggling of Migrants. ${ }^{89}$

The next question is: How may this development affect the applicability of ECHR on the high seas? Would an administrative or judicial act, such as the issuance of a decree of seizure, which would possibly constitute a breach of the freedom of navigation, suffice to bring about the application of ECHR?

On the one hand, in my view, such an act would fall short of reaching the jurisdictional threshold of Article 1 of the ECHR. While such administrative or judicial acts or orders, including the order to seize or close ports to vessels having rescued migrants at sea, ${ }^{90}$ constitute, in principle, executive acts of the State, they are not of such nature to establish the control and authority of that State over the persons concerned, as required by the case law of ECtHR. To put it differently, they are assimilated to assertions of prescriptive jurisdiction over persons extraterritorially, which still require to be physically executed or enforced. For example, in the $M / V$ Norstar case above, the Decree of Seizure issued by the Public Prosecutor at the Court of Savona, Italy — which, according to the Tribunal, sufficed in itself to constitute a violation of the freedom of navigation on the high seas-still required its execution, enforcement jurisdiction, in that case by Spanish authorities at the port of Palma de Mallorca, Spain. ${ }^{91}$ It is this execution or enforcement, for present purposes on the high seas, that would constitute authority and control and thereby trigger the application of the ECHR, and not the mere issuance of a decree by the competent national authorities.

On the other hand, the concept of a chilling effect, albeit in a different sense than in the Norstar judgment above, ${ }^{92}$ may indeed inform the discussion over the extraterritorial application of ECHR. It lends support to the claim that not only the boarding and search of a foreign vessel on the high seas, but also any act of a State vessel on the high seas that may have a chilling effect on the vessel concerned is capable of establishing the jurisdiction of the ECHR. Accordingly, any act of a State vessel, even short of boarding, ${ }^{93}$ that effectuates the stopping or the diversion of the vessel in question could trigger the application of ECHR, because it would clearly amount to an exercise of control and authority over the vessel and the persons on board. Such acts may include the hailing of the vessel, ordering it to stop or divert its course, and any kinetic or other action to this effect. ${ }^{94}$ Suffice it to recall here that such diversion of course, by warning the vessel and placing a warship at its route, was sufficient for the ECtHR to find its jurisdiction in the Women on Waves case. ${ }^{95}$

In conclusion, the exercise of enforcement jurisdiction at sea, as framed and conceived by the law of the sea, may also have certain influence on how jurisdiction in terms of Article 1 of the

\footnotetext{
${ }^{89}$ See Smuggling of Migrants Protocol arts. 1(3), 6, in conjunction with the U.N. Convention Against Transnational Organized Crime, art. 15, Dec. 12, 2000, 40 ILM 335 (2001), U.N. Doc. A/55/383, at 25.

${ }^{90} \mathrm{Cf}$. the recent Italian practice of NGO vessels rescuing people at sea, which led, amongst others, to the Aquarius incident. See also Efthymios Papastavridis, Recent Non-Entrée Policies in the Central Mediterranean and Their Legality: A New Form of Refoulement?, 12 DiritTi UMANI E DiRITTO INTERNAZIONALE 493 (2018); Gombeer \& Fink, supra note 65; Violeta Moreno-Lax et al., Between Life, Security and Rights: Framing the Interdiction of "Boat Migrants" in the Central Mediterranean and Australia, 32 LeIDEN J. INT'L L. 715 (2019).

${ }^{91} M / V$ Norstar Case, Case No. 25 at para. 74.

${ }^{92} \mathrm{M} / \mathrm{V}$ Norstar Case, Case No. 25 at para. 206.

${ }^{93}$ Cf. Hirsi Case, App. No. 27765/09; Medvedyev Case, App. No. 3394/03 (comparing the findings of the ECtHR inter alia).

${ }^{94}$ For example, in the Rules of Engagement of the EUNAVFOR Operation Sophia off the coast of Libya, there is reference to the possibility of the use of electromagnetic pulses to stop a vessel smuggling migrants, which would clearly fall under the jurisdictional clause of ECHR, even though lacking physical contact. See Efthymios Papastavridis, EUNAVFOR Operation Sophia and the International Law of the Sea, 2 MARSAFELAW J. 57, 66 (2016) (with further references therein). On the conduct of interception operations in general, see, for example, PAPASTAVRIDIS, supra note 23, at 66-73.

${ }^{95}$ See Women on Waves Case, App. No. 31276/05.
} 
ECHR is construed in the maritime domain. Even without subjecting any executive act of the State on land amounting to a legal interference with navigation à la Norstar to the ECHR, it is, however, contended that any act of a State vessel having a chilling effect or resulting in the diversion of vessels on the high seas would trigger the application of the ECHR.

\section{Search and Rescue Operations}

The majority of incidents involving maritime migration that may have human rights implications occur in the context of search and rescue operations (SAR operations). ${ }^{96}$ Similarly to the interception operations above, it is questioned whether States do exercise jurisdiction in this regard under the law of the sea and how this jurisdiction can be imported to the human rights discourse.

\section{Flag State}

Briefly, under the law of the sea, the LOSC prescribes the duty to rescue at sea for both flag and coastal States. First, with regard to flag States, Article 98(1) of LOSC provides that:

Every State shall require the master of a ship flying its flag, in so far as he can do so without serious danger to the ship, the crew, or the passengers ... to render assistance to any person found at sea in danger of being lost ... and to proceed to the rescue of persons in distress, if informed of their need for assistance, in so far as such action may be reasonably be expected of him.

On the face of Article 98(1) of LOSC, it is apparent that the responsibility to rescue and provide assistance rests initially with the master of the rescuing ship and entails also the duty to deliver the rescued people to a place of safety. ${ }^{97}$ With respect to the obligations of the flag State as such, it must require the master of a ship, whether a State or private ship flying the State's flag, to proceed with all possible speed to the rescue of persons in distress, ${ }^{98}$ when informed of their need for assistance. Article 98(1) is non-self-executing and requires implementing legislation to acquire the force of law. ${ }^{99}$ Besides this, there is no other obligation of result, such as an obligation to guarantee that the people in distress will be saved. ${ }^{100}$ In addition, the flag State is under a "due diligence" obligation to monitor whether the masters of vessels flying its flag discharge these duties. ${ }^{101}$ The due diligence obligations of flag States were discussed at length in the ITLOS Advisory Opinion of 2 April 2015 on the Request of the Sub-Regional Fisheries Commission, in which the Tribunal

\footnotetext{
${ }^{96}$ Among the recent applications, see Safi Case, App. No. 5418/15; Stone, supra note 3 (analyzing the C.O. and A.J. v. Italy case). Both cases are still pending.

${ }^{97}$ The term "place of safety" is defined in the 2004 IMO Guidelines on the Treatment of Persons Rescued at Sea as any place where the survivors' safety of life is no longer threatened and where their basic human needs such as food, shelter and medical needs can be met. See International Maritime Organization Res. MSC.167(78), U.N. Doc. MSC 78/26/Add.2 (May 20, 2004).

98"Distress" is not defined by LOSC; yet the term "distress phase" has been defined as "a situation wherein there is a reasonable certainty that a person, a vessel or other craft is threatened by grave and imminent danger and requires immediate assistance." See International Convention on Maritime Search and Rescue, annex, para. 1.3.13, June 22, 1985, 1405 U.N.T.S. No. 23489 (emphasis added) [hereinafter SAR Convention].

${ }^{99}$ Richard Barnes, Refugee Law at Sea, 53 INT'L \& COMP. L.Q. 14, 50 (2014) (reporting that, "in the UK the master has a duty, upon receiving a distress signal, to proceed to their assistance, unless he is unable .... Failure to do so is a criminal offence").

${ }^{100}$ For more on the classification of obligations, for example, between obligations of result and obligations of conduct in international law, see, inter alia, Jean Combacau, Obligations de résultat et obligations de comportement: quelques questions et pas de réponse, in Mélanges offerts à PAul Reuter: Le Droit InTERnational, unité et diversité 181 (1981).

${ }^{101}$ See generally Yoshinobu Takei, Assessing Flag State Performance in Legal Terms: Clarifications of the Margin of Discretion, 28 INT'L J. MARINE \& COASTAL L. 97-133 (2013) (explaining the obligations of flag States).
} 
acknowledged that the flag States are under such obligations in relation to Illegal, Unregulated and Unreported Fishing (IUU Fishing) within the EEZ of third States. ${ }^{102}$ It can tenably be argued that the same reasoning applies mutatis mutandis in relation to the rescue obligations of the flag States under Article 98(1) of LOSC. Accordingly, Article 98(1) LOSC, in conjunction with Article 94 LOSC, which sets out in a non-exhaustive manner the duties of the flag States, ${ }^{103}$ involves an obligation not only to adopt appropriate national rules and measures but also to exercise "a certain level of vigilance in their enforcement," including exercising "administrative control" over relevant "public and private operators." 104

When it comes to the application of the ECHR to the case of rescue or non-rescue of persons at sea and the potential responsibility of the flag State in this regard, the following remarks, first, with respect to State vessels, are in order: In light of the ECtHR case law discussed above, it is doubtless that the persons brought onboard a rescuing State vessel would come under the jurisdiction of that flag State for ECHR purposes. ${ }^{105}$ Nevertheless, the ECHR could be considered as applicable not only when the persons are rescued, but even prior to this, namely when the State vessel concerned, being aware of the distress situation, has established contact with the vessel or persons in danger. ${ }^{106}$ In other words, from the moment that a State vessel, having the requisite visual contact with the vessel or persons in distress, is called to execute its duty to render assistance in accordance with Article 98(1) LOSC and the relevant national law- "enforcement jurisdiction" under law of the sea-it starts at the same time to exercise authority and control over these persons, sufficient to trigger the application of the ECHR. To recall the ECtHR in the Jaloud case, the particular factual context-positive knowledge of the distress situation-and the relevant rules of international law (LOSC) should be taken into account for the purposes of establishing the jurisdiction of the State concerned. ${ }^{107}$

Under such circumstances, the right of most immediate concern is the right to life, enshrined in Article 2 of the ECHR. ${ }^{108}$ As has been consistently held by the ECtHR since the 1999 Osman case, Article 2 requires States not only to refrain from causing death but also to take positive measures to protect the lives of individuals within their jurisdiction. ${ }^{109}$ Particularly, positive obligations come into play when the national authorities "knew or ought to have known the existence of a real and imminent risk to the life of an identified individual and that they failed to take measures within the scope of their powers which, judged reasonably, might have been expected to avoid that risk." 110 As the current President of the ECtHR Sicilianos observes, a number of conditions must be fulfilled for a violation of Article 2 to be established:

\footnotetext{
${ }^{102}$ Request for an Advisory Opinion Submitted by the Sub-Regional Fisheries Commission, Case No. 21, Advisory Opinion of Apr. 2, 2015, paras. 16-141, https://www.itlos.org/fileadmin/itlos/documents/cases/case_no.21/advisory_opinion_published/ 2015_21-advop-E.pdf [hereinafter ITLOS Advisory Opinion].

${ }^{10}$ LOSC art. $94 ;$ id. at para. 117.

${ }^{104}$ Pulp Mills on the River Uruguay (Arg. v. Uru.), Judgment, 2010 I.C.J. Reports 14, 197 (Apr. 20, 2010).

${ }^{105}$ Hirsi Case, App. No. 27765/09 at para. 81; Medvedyev Case, App. No. 3394/03 at para. 67.

${ }^{106}$ This contact with the vessel in distress and the knowledge of the situation can also be established by sending a helicopter or other aerial means-for example, the use of drones-by the State vessel concerned.

${ }^{107}$ Jaloud Case, App. No. 47708/08 at para. 141.

${ }^{108}$ ECHR art. 2 ("Everyone's right to life shall be protected by law. No one shall be deprived of his life intentionally save in the execution of a sentence of a court following his conviction of a crime for which this penalty is provided by law.").

${ }^{109}$ See Osman v. United Kingdom, App. No. 23452/94 (Oct. 28, 1998), http://hudoc.echr.coe.int/eng?i=001-58257 [hereinafter Osman Case]. See also Furdík v. Slovakia, App. No. 42994/05 (Dec. 2, 2008), http://hudoc.echr.coe.int/eng?i=00190321; Kemaloglu v. Turkey, App. No. 19986/06 (Apr. 10, 2012), http://hudoc.echr.coe.int/eng?i=001-110253 (describing the positive obligation dimension of this right).

${ }^{110}$ Osman Case, App. No. 23452/94 at para. 11. On the positive obligations under Article 2 of ECHR, see Linos-Alexander Sicilianos, Preventing Violations of the Right to Life: Positive Obligations Under Article 2 of the ECHR, 3 CYPRUS HUM. RTs. L. REV. 117 (2014).
} 
Knowledge of the authorities, either actual or presumed, is the first of them ... The existence of a real and imminent risk is the second condition ... The risk should concern an identified individual . . . Finally, the fourth condition relates to the failure of state authorities to take appropriate measures to avoid or minimize the risk. In other words, a causal link should exist between the inactivity of the State and the loss of life. ${ }^{111}$

These conditions would be assessed in cases in which a State vessel, having established contact with the vessel in distress and thus having places the people on board within its jurisdiction for ECHR purposes, failed to discharge the duty to rescue at sea. ${ }^{112}$

On the contrary, the situation is different where rescue operations are conducted by private vessels. In such cases, there is no jurisdictional link between the rescued persons and the flag State. Nevertheless, such link could, arguably, be established in the case that the master was given specific instructions from the competent authorities of the flag State as to how it should proceed with the persons concerned and acted accordingly. In that case, the conduct would be attributed to the flag State under Article 8 of the ILC Articles on Responsibility of States for Internationally Wrongful Acts (ARSIWA). ${ }^{113}$ Does this suffice to bring about the application of the ECHR? Even though attribution of conduct is conceptually different than the issue of jurisdictionthe former is an issue under Article 2(a) of the ARSIWA, ${ }^{114}$ while jurisdiction is an issue under Article 2(b), which asks did that obligation even apply to that particular conduct? ${ }^{115}$ — this seems here as jurisdiction establishing conduct, ${ }^{116}$ through which the flag State assumes control over the persons in need of rescue in this particular case. Even in that case, though, the violation of the positive obligation under Article 2 of the ECHR would still need to be established.

\section{Coastal States}

With regard to coastal States, Article 98(2) of LOSC stipulates:

Every coastal State shall promote the establishment, operation and maintenance of an adequate and effective search and rescue service regarding safety on and over the sea and, where circumstances so require, by way of mutual regional arrangements cooperate with neighbouring States for this purpose.

\footnotetext{
${ }^{111}$ Sicilianos, supra note 110, at 119 (referencing further supporting case law therein).

${ }^{112}$ Allegations of this character were made against warships of various European nations taking part in the NATO operation against Libya in March 2011. See Jack Shenker, Aircraft Carrier Left Us to Die, Say Migrants, The GuARDIAN (May 8, 2011), http:// www.guardian.co.uk/world/2011/may/08/nato-ship-libyan-migrants. See also Eur. Parl. Ass., Lives Lost in the Mediterranean Sea: Who Is Responsible?, Doc. No. 12895 (2012), https://assembly.coe.int/CommitteeDocs/2012/20120329_mig_RPT.EN.pdf; Efthymios Papastavridis, The 'Left-to-Die Boat' Incident of March 2011: Questions of International Responsibility Arising From the Failure to Save Refugees at Sea (Refugee L. Initiative, Working Paper No. 10, 2013), http://sasspace.sas.ac.uk/4957/1/ RLI_Working_Paper_No.10.pdf.

${ }^{113}$ The conduct of a person or group of persons shall be considered an act of a State under international law if the person or group of persons is in fact acting on the instructions of, or under the direction or control of, that State in carrying out the conduct. See Responsibility of States for Internationally Wrongful Acts, UNGAOR, 56th sess., Supp. No. 10, U.N. Doc. A/56/ 10; at 31 art. 8 (emphasis added) [hereinafter ARSIWA]; http://untreaty.un.org/ilc/texts/instruments/english/commentaries/ 9_6_2001.pdf. See also James Crawford, State Responsibility: The General Part 144-46 (2014), for information on persons acting on state "instructions."

${ }^{114}$ Under Article 2 of the ARSIWA, "[t]here is an internationally wrongful act of a State when conduct consisting of an action or omission: (a) is attributable to the State under international law; and (b) constitutes a breach of an international obligation of the State." ARSIWA, supra note 113.

${ }^{115}$ See the pertinent remarks of Milanovic in his EJIL post commenting on the Jaloud case. Marko Milanovic, Jurisdiction, Attribution and Responsibility in Jaloud, EJIL: TALK! (Dec. 11, 2014), https://www.ejiltalk.org/jurisdiction-attribution-andresponsibility-in-jaloud/.

${ }^{116} I d$.
} 
The search and rescue regime under LOSC is complemented by the SOLAS Convention, ${ }^{117}$ but mainly by the 1979 International Convention on Maritime Search and Rescue (SAR Convention). ${ }^{118}$ The SAR Convention aims to create an international system for coordinating rescue operations and guaranteeing their efficiency and safety. Contracting States are obliged to provide SAR services in the area under their responsibility and are invited to regulate and coordinate operations and rescue services in that area (SAR region or area). ${ }^{119}$

In particular, the obligations of the coastal States are as follows: First, there is an obligation to "promote the establishment, operation and maintenance of adequate and effective search and rescue services." 120 The coastal State is thus bound by an obligation to establish search and rescue services, but is also bound by an obligation of due diligence, pursuant to which it has to make sure that adequate and effective SAR services are maintained in its SAR region. Second, in case of a distress situation, the coastal State is under a twofold obligation: On the one hand, it "shall, so far as possible, provide adequate means of locating and rescuing such persons"121 and coordinate search and rescue activities and, on the other hand, cooperate with other States to this end. ${ }^{122}$ As regards the former obligation, it is submitted that the coastal States have to discharge "best efforts obligations," to use Crawford's terminology, ${ }^{123}$ namely to deploy all adequate measures so as to provide rescue services in order to save the persons in distress, but not an "obligation of result," for example to guarantee that these peoples would be saved in any case whatsoever. This means that if the persons in distress are not saved, notwithstanding these "best efforts," the coastal State concerned does not automatically or ipso jure incur responsibility. As to the actual SAR operating procedures, these are laid down, in detail, in the Annex of the SAR Convention. Of relevance to the present inquiry is, first, that a situation of distress is predicated upon the "reasonable certainty that a person, a vessel or other craft is threatened by grave and imminent danger and requires immediate assistance." 124 Second, instrumental to any SAR operation is the designation of an on-scene coordinator, who would coordinate on the scene the activities of search and rescue units and other facilities engaged in SAR to ensure the most effective results and would report back to the Rescue Coordination Center. ${ }^{125}$ Needless to say that, in executing these provisions under the SAR Convention and the implementing national legislation, the State organs are exercising enforcement jurisdiction under the relevant international law of the sea.

Similar to the other maritime activities above, it is questioned when the exercise of such enforcement jurisdiction for SAR purposes would trigger the application of ECHR and thus the potential responsibility of the coastal State involved. The answer lies, as the ECtHR stated in the Jaloud case, in the factual situation and the relevant rules of international law, here the rules on SAR. From these considerations follows that once, first, positive identification of the situation of distress has been made, even with the use of "reliable advanced technology (satellite surveillance, over-the-horizon radar, unmanned aerial vehicles),"126 which would meet the

\footnotetext{
${ }^{117}$ See International Convention for the Safety of Life at Sea, Ch. V, Nov. 1, 1974, 1184 U.N.T.S. 278 [hereinafter the SOLAS Convention].

${ }^{118}$ See SAR Convention.

${ }^{119}$ See also SOLAS Convention reg. 7; Seline Trevisanut, Search and Rescue Operations in the Mediterranean: Factor of Cooperation or Conflict?, 25 INT'L J. MARINE \& COASTAL L. 523, 524 (2010).

${ }^{120}$ LOSC art. 98(2); SOLAS Convention ch. V, reg. 7.

${ }^{121}$ SOLAS Convention ch. V, reg. 7.

${ }^{122}$ SAR Convention, annex I, ch. 3.

${ }^{123}$ As summarized by Crawford, "obligations of result involve in some measures a guarantee of the outcome, whereas obligations of conduct are in the nature of best efforts obligations, obligations to do all in one's power to achieve a result, but without ultimate commitment." James Crawford, Second Report on State Responsibility, para. 67, U.N. Doc. A/CN.4/498 (July 19, 1999). See also Combacau, supra note 100.

${ }^{124}$ For the definition of distress under the SAR Convention, see SAR Convention, supra note 98.

${ }^{125}$ SAR Convention, annex 4.7.

${ }^{126}$ Arctic Sunrise Case, Case No. 2014-02 at para. 260.
} 
reasonable certainty criterion above, ${ }^{127}$ and, second, the on the scene coordinator has arrived at the area, the coastal State becomes obligated under the ECHR to secure the rights of the people in distress - first and foremost, the right to life. Even though the coastal State's obligations under the law of the sea, in particular under SAR Convention, may arise earlier-for example, in the uncertainty phase, "a phase wherein uncertainty exists as to the safety of a person or a vessel," 128 - in the context of ECHR, the "game changer" becomes, in my view, the positive knowledge of the distress situation in conjunction with the presence of the "search and rescue units" 129 or "facilities"130 on the scene. ${ }^{131}$ Knowledge or reasonable certainty of the distress situation alone does not suffice, because the element of the "physical control and authority," which the presence of the on-thescene coordinator and the rescue units reassure, would be missing. Should both elements exist, the persons come under the authority and control of these units and thus within the jurisdiction of the coastal State for ECHR purposes. Notably, it does not matter whether the search and rescue units or facilities engaged in the SAR operation are State or private vessels of the same nationality as the coastal State or not, ${ }^{132}$ because the critical element here is that they are under the directions of the Rescue Coordination Center (RCC) through the on-scene coordinator. ${ }^{133}$

The establishment of the jurisdiction of the State concerned over the persons in distress at sea does not necessarily entail the responsibility of that State for the violation of the respective rights under the ECHR. As stated above, there are certain conditions that the ECtHR would assess in this regard. ${ }^{134}$ In addition, the due diligence that the search and rescue units had displayed in the circumstances of each case would inevitably be taken into account. This due diligence examination would necessarily be informed by the operational plans of the SAR under scrutiny, as developed by the responsible RCC. ${ }^{135}$ It follows that the relevant rules of international law, for example, those of the law of the sea, ought to influence the ECtHR's reasoning with respect both to the jurisdiction and the merits.

\section{Concluding Thoughts}

In all applications before the ECtHR concerning migration at sea, a perennial question is whether the applicants were within the jurisdiction of the respondent State in terms of Article 1 of the ECHR. Such questions become even more perplexing in contemporary situations of remote interception or SAR operations - aptly coined as contactless control—and, of course, more apposite, in view of the relevant applications against Italy before the ECtHR.

In addressing the matter of jurisdiction in such cases, the law of the sea becomes of significant importance. It is impossible to examine whether jurisdiction under the ECHR had been established in cases involving interception or SAR on the high seas without having a good grasp of how jurisdiction is construed and implemented under the law of the sea. Far from resurrecting Banković and the strict general international law notion of jurisdiction under ECHR, this Article's

\footnotetext{
${ }^{127}$ SAR Convention.

${ }^{128}$ SAR Convention, annex 1.3.11.

129"Search and rescue unit" is defined as "a unit composed of trained personnel and provided with equipment suitable for the expeditious conduct of search and rescue operations." SAR Convention, annex 1.3.8.

130"Search and rescue facility" is defined as "[a]ny mobile resource, including designated search and rescue units, used to conduct search and rescue operations." SAR Convention, annex 1.3.7. These facilities might be foreign private vessels in the vicinity of the distress area.

${ }^{131}$ For a different and more expansive view, see Seline Trevisanut, Is There a Right to be Rescued at Sea? A Constructive View, 4 QUESTIONS INT'L L., ZOOM-IN 3 (2014).

${ }^{132} \mathrm{~A}$ search and rescue unit engaged in the SAR might belong to another cooperating State. On inter-State cooperation, see SAR Convention, annex, chs. 3, 4.6.

${ }^{133}$ As provided, "specific responsibilities shall be assigned to the on-scene co-ordinator, taking into account the apparent capabilities of the on-scene co-ordinator and operational requirements." SAR Convention, annex 4.7.2.

${ }^{134}$ See Sicilianos, supra note 110 , and accompanying text.

${ }^{135}$ See SAR Convention, annex 4.1.
} 
purpose was to put some context to the factual assessment that the Court commonly takes to establish the jurisdiction of the respondent State and argue that the relevant rules of the international law of the sea should be taken into serious account.

Such rules are mainly the rules under the LOSC and other relevant instruments, including the SAR Convention, as have been interpreted by international courts and tribunals, such as ITLOS in the Norstar case. A common thread identified in this respect is that usually when States are exercising enforcement jurisdiction on the high seas with the requisite knowledge of the situation and with physical contact with the persons concerned, the ECHR comes also into play.

Accordingly, in cases like S.S. and others $v$. Italy, ${ }^{136}$ these two issues-for example, the knowledge of the distress situation and the control over the persons concerned-would, in my view, be decisive in order for the ECtHR to establish its jurisdiction. In that case, which involved the acts of Libyan rescue units, in order to establish that they had been within the jurisdiction of Italy, the applicants should substantiate that the Italian authorities were in full knowledge of the distress situation, that they had designated an on-the-scene coordinator, and that they had instructed him or her to take specific action vis-à-vis the persons in distress. Even then, the Court should assess whether the loss of lives at sea amounted to a violation of the positive obligations of Italy under Article 2 ECHR. In that assessment, the SAR rules may prove very helpful for the Court in examining the due diligence of Italy in this regard. In the same vein, in the Safi and others $v$. Greece case, ${ }^{137}$ whilst the jurisdiction issue poses no problem, because the applicants were readily within the jurisdiction of the Greek authorities, the actual violation of Article 2 ECHR could also be assessed against the background of the relevant SAR rules. Finally, in the C.O. and A.J. v. Italy case, ${ }^{138}$ the applicants have the hard task to prove that the diversion of the $M / V$ Aquarius was due to physical executive or enforcement actions by the Italian authorities. ${ }^{139}$

\footnotetext{
${ }^{136}$ See more on this case supra note 2.

${ }^{137}$ See Safi Case, App. No. 5418/15.

${ }^{138}$ See Stone, supra note 3; Papastavridis, supra note 3.

${ }^{139}$ M/V Norstar Case, Case No. 25 at para. 206. See Women on Waves Case, App. No. 31276/05. Cf. Hirsi Case, App. No. 27765/09; Medvedyev Case, App. No. 3394/03 (comparing the findings of the ECtHR inter alia); Papastavridis supra note 94, at 66 , and accompanying text; PAPASTAVRIDIS, supra note 23 , at 66-73.
}

Cite this article: Papastavridis E (2020). The European Convention of Human Rights and Migration at Sea: Reading the "Jurisdictional Threshold" of the Convention Under the Law of the Sea Paradigm. German Law Journal 21, 417-435. https://doi.org/10.1017/glj.2020.23 